\title{
P04.57. Music therapy in the treatment of cancer patients: a systematic review
}

\author{
T Ostermann $^{1 *}$, C Boyde ${ }^{2}$, U Linden ${ }^{2}$ \\ From International Research Congress on Integrative Medicine and Health 2012 \\ Portland, Oregon, USA. 15-18 May 2012
}

\section{Purpose}

Creative therapies like painting, speech therapy, healing eurythmic dance therapy and music therapy are frequently used in the treatment of cancer patients. Particularly in the last decade, several studies have concentrated on the investigation of effects of music therapy in cancer patients.

\section{Methods}

The following databases were used to find studies of music therapy in oncology: AMED, CAIRSS, EMBASE, MEDLINE, PsychINFO, and PSYNDEX. The search terms were ["Study OR Trial" AND "Music Therapy" AND "Cancer or Oncology"]. Included studies were analysed with respect to their study design and quality, setting and interventions including date of publication, indications, patients and main outcomes.

\section{Results}

We found a total of 12 clinical studies conducted between 2001 and 2011 including a total of 922 patients. Eight studies had a randomized controlled design and four studies were conducted in the field of pedeatric oncology. Both type and grading of cancer were heterogenous thoughout all studies. Active music making $(\mathrm{n}=7)$ as well as listening programs $(\mathrm{n}=5)$ were mostly enrolled after surgery or chemotherapy to improve the patient's situation. Studies reported on short term improvements in patient's mood, relaxation, lowering exhaution and anxiety as well as in coping with the disease and cancer related pain.

\section{Conclusion}

The use of music therapy in the integrative treatment of cancer patients is a therapeutic option, whose

'University of Witten/Herdecke, Herdecke, Germany

Full list of author information is available at the end of the article salutogenetic potential is shown in many case studies. Study results however did not draw a conclusive picture on the overall effect of music therapy. Research therefore should investigate the underlying mechanisms to come to a more conclusive hypothesis.

Author details

${ }^{1}$ University of Witten/Herdecke, Herdecke, Germany. ${ }^{2}$ Department of Music Therapy, Community Hospital Herdecke, Herdecke, Germany.

Published: 12 June 2012

doi:10.1186/1472-6882-12-S1-P327

Cite this article as: Ostermann et al:: P04.57. Music therapy in the treatment of cancer patients: a systematic review. BMC Complementary and Alternative Medicine 2012 12(Suppl 1):P327.
Submit your next manuscript to BioMed Central and take full advantage of:

- Convenient online submission

- Thorough peer review

- No space constraints or color figure charges

- Immediate publication on acceptance

- Inclusion in PubMed, CAS, Scopus and Google Scholar

- Research which is freely available for redistribution

Submit your manuscript at www.biomedcentral.com/submit

\section{() Biomed Central}

\section{Ciomed Central}

